\title{
A lake as a microcosm: reflections on developments in aquatic ecology
}

Hansson, Lars-Anders; Brodersen, Jakob; Chapman, Ben B.; Ekvall, Mattias K.; Hargeby, Anders; Hulthén, Kaj; Nicolle, Alice; Nilsson, P. Anders; Skov, Christian; Brönmark, Christer

Published in:

Aquatic Ecology

Link to article, DOI:

10.1007/s10452-013-9435-2

Publication date:

2013

Document Version

Publisher's PDF, also known as Version of record

Link back to DTU Orbit

Citation (APA):

Hansson, L-A., Brodersen, J., Chapman, B. B., Ekvall, M. K., Hargeby, A., Hulthén, K., Nicolle, A., Nilsson, P. A., Skov, C., \& Brönmark, C. (2013). A lake as a microcosm: reflections on developments in aquatic ecology. Aquatic Ecology, 47, 125-135. https://doi.org/10.1007/s10452-013-9435-2

\section{General rights}

Copyright and moral rights for the publications made accessible in the public portal are retained by the authors and/or other copyright owners and it is a condition of accessing publications that users recognise and abide by the legal requirements associated with these rights.

- Users may download and print one copy of any publication from the public portal for the purpose of private study or research.

- You may not further distribute the material or use it for any profit-making activity or commercial gain

- You may freely distribute the URL identifying the publication in the public portal 


\title{
A lake as a microcosm: reflections on developments in aquatic ecology
}

\author{
Lars-Anders Hansson - Jakob Brodersen - Ben B. Chapman • \\ Mattias K. Ekvall • Anders Hargeby • Kaj Hulthén • Alice Nicolle • \\ P. Anders Nilsson $\cdot$ Christian Skov $\cdot$ Christer Brönmark
}

Received: 3 May 2012/ Accepted: 12 March 2013

(C) Springer Science+Business Media Dordrecht 2013

\begin{abstract}
In the present study, we aim at relating Forbes' remarkable paper on "The lake as a microcosm", published 125 years ago, to the present status of knowledge in our own research group. Hence, we relate the observations Forbes made to our own microcosm, Lake Krankesjön in southern Sweden, that has been intensively studied by several research groups for more than three decades. Specifically, we focus on the question: Have we made any significant progress or did Forbes and colleagues blaze the trail through the unknown wilderness and we are mainly paving that intellectual road? We conclude that lakes are more isolated than many other biomes, but have, indeed, many extensions, for example, input from the catchment, fishing and fish migration. We also conclude that irrespective of whether lakes should be viewed as microcosms or not, the paper by Forbes has been exceptionally influential and still is, especially since it touches upon almost all aspects of the lake ecosystem, from individual behaviour to food web interactions and environmental issues. Therefore, there is no doubt that even if 125 years have passed,
\end{abstract}

Handling Editor: Thomas Mehner.

L.-A. Hansson ( $₫)$ · J. Brodersen - B. B. Chapman ·

M. K. Ekvall - A. Hargeby · K. Hulthén .

A. Nicolle · P. A. Nilsson · C. Skov · C. Brönmark Institute of Biology/Aquatic Ecology, Lund University, Ecology Building, 22362 Lund, Sweden

e-mail: lars-anders.hansson@biol.lu.se
Forbes' paper still is a source of inspiration and deserves to be read. Hence, although aquatic ecology has made considerable progress over the latest century, Forbes might be viewed as one of the major pioneers and visionary scientists of limnology.

Keywords Forbes - Microcosm - Trophic cascade . Zooplankton · Fish $\cdot$ Food web

\section{Introduction}

To honour the 125-year anniversary of Forbes' remarkable paper on "The lake as a microcosm" (Forbes 1887; reprinted 1926), we were invited to write a paper reflecting on this pioneering work, but also on the advances aquatic ecology and limnology has made since then. Based on these prerequisites, we decided to relate the observations Forbes made to our own microcosm, Lake Krankesjön in southern Sweden, that has been intensively studied by several research groups for more than three decades. Hence, we here aim to put our own studies into the context of what Forbes observed 125 years ago and specifically focus on the question: Have we made any significant progress or did Forbes and colleagues blaze the trail through the unknown wilderness and we are mainly paving that intellectual road? This means that here we will mainly refer to studies performed in one lake by one research group, although we are fully aware of that 
our studies might not in all cases illustrate the research front and we indeed acknowledge the advancements made by other groups. However, since research groups as ours are by no means working in isolation, but communicate with the research community through publications, congresses and collaborations, our specific research group may reasonably well mirror the level of general progress in relation to Forbes' study performed a century ago. Hence, we believe there is some general understanding to gain, and possibly also a general interest as a historical document by relating one thoroughly studied "microcosm", in this case L. Krankesjön, Sweden (Box 1), to what Forbes described from some American lakes a century ago.

First of all it might be worth contemplating somewhat about why Forbes' paper has remained influential for more than a century and, in addition, is now celebrated in a renowned journal as Aquatic Ecology. Obviously, the number of journals and publications has increased tremendously since 1887 so a lot of excellent studies are probably hidden in the noise. However, some attributes might be possible to identify, for example, that the paper by Forbes was based on solid data (but not necessarily better than what is produced today), had a title which still is very provocative saying that lakes are something closed from other biomes-they are microcosms. Forbes expressed the microcosm idea as: “... if every terrestrial animal were suddenly annihilated it would doubtless be long before the general multitude of the inhabitants of the lake would feel the effect of this event in any important way" (Forbes 1926); p. 537; note that we will here refer to the 1926 edition. Although thought provoking, this may not be completely correct, and in the present paper, we aim at addressing the potential extensions such a microcosm might have. Although Forbes' paper is not scientifically very precise and expressions like " 16 or so bivalves were found" are common, most circumstantial or esoteric sections end with a reflective paragraph. Those reflections were made in the spirit of the time and were very provocative and constituted a signal of what should come. Hence, Forbes' paper was very timely, appearing just after Darwin's book on "The Origin of Species" (Darwin 1859), and also broke new ground by not only observing, but also synthesizing the observations and making connections between abiotic and biotic processes and thereby setting the stage for a new integrative discipline: Ecology.

In the present paper, we have subjectively selected some of Forbes' reflections and will below relate these to our present knowledge. Hence, we will use citations from Forbes' paper, and provide examples of where, and in what way, research has made advancements (or not) since then. As a starting point, we will consider thoughts which illustrate the dawn of modern ecological research.

\section{The dawn of ecology and cascading trophic interactions}

"If one wishes to become acquainted with the black bass, for example, he will learn but little if he limits himself to that species” p. 537 (Forbes 1926).

This way of thinking is currently a central tenet of ecology, that is, a specific organism has to be studied in the context of its environment. Moreover, Forbes also explicitly pointed out cascading trophic interactions (Carpenter et al. 1985), which is an expansion of

\section{Box 1 About Lake Krankesjön}

Lake Krankesjön is situated in southern Sweden $\left(55^{\circ} 42^{\prime} \mathrm{N}, 13^{\circ} 28^{\prime} \mathrm{E}\right)$ and has a drainage area of $53 \mathrm{~km}^{2}$, mainly consisting of open fields (about $70 \%$ ) and forests (15\%). The lake covers an area of $2.9 \mathrm{~km}^{2}$ and has a mean depth of $0.9 \mathrm{~m}$ (Hargeby et al. 1994 ; Blindow et al. 2006). With an average summer total phosphorus concentration of $38 \mu \mathrm{g} \mathrm{L}^{-1}, 1.3 \mathrm{mg} \mathrm{L}^{-1}$ nitrogen and $17 \mu \mathrm{g} \mathrm{L}^{-1}$ chlorophyll- $a$, L. Krankesjön is moderately eutrophic (Hargeby et al. 1994). During periods with clear water, the bottom is covered with submerged plants, especially charophytes, which dominate the bottom vegetation of most of the lake. Smaller areas with Potamogeton pectinatus also occur. The lake is fringed by reeds Phragmites australis that form more extensive beds in the western and south-eastern parts of the lake. In the eastern part, there are also a few small, isolated clumps of reeds as well as low, island-like stands of mainly Acorus calamus and Sparganium. The cover (\%) of submersed macrophytes was estimated by mapping from boat during July or August, complemented with estimates from aerial photographs

The planktivorous fish roach (Rutilus rutilus) is the most abundant fish species in the lake. Other planktivorous and benthivorous species common in Krankesjön are rudd (Scardinius erythrophtalmus (L.)), tench (Tinca tinca), bream (Abramis brama (L.)) and white bream (Blicca bjoerkna (L.)). Piscivorous fish species common in Krankesjön are perch (Perca fluviatilis) and pike (Esox lucius) (Hansson et al. 2007) 
the food web theory (Lindeman 1942; Hairston et al. 1960; Hrbácek et al. 1961), by stating that top predators may indeed affect the abundance of their prey, that is, top-down control, for example:

Evidently each of this classes must act as a check upon the one preceding it. The development of animalcules (small animals; our clarification) is arrested and soon sent back below its highest point by the consequent development of Entomostraca; the latter, again, are met, checked, and reduced in number by the innumerable shoals of fishes with which the water speedily swarms (pp. 538-539).

and:

Next, looking to the food of the species which the bass (predator; our clarification) has eaten, and upon which it is therefore indirectly dependent, I find that one kind of the fishes taken feeds upon mud, algae and Entomostraca (old expression of a subclass of Crustacea; our clarification), and other upon nearly every animal substance in the water, including molluscs and decomposing organic matter ... At only the second step, therefore, we find our bass brought into dependence upon nearly every class of animals in the water (pp. 547-548).

This paragraph describes in a very illustrative way how feeding links "cascade" through several trophic levels, and although a multitude of studies, both theoretical and empirical, have fine tuned the concept and quantified many of the links, the observations Forbes provided are still valid. Moreover, in addition to observing food web interactions, Forbes also noted that predation is a very important structuring force.

\section{Predator-prey interactions}

But the enemies of these bass do not all attack by appropriating its food supplies, for many devour the little fish itself. A great variety of predaceous fishes, turtles, water snakes, wading and diving birds and even bugs of gigantic dimensions destroy it on the slightest opportunity (p. 548).

In addition to pointing out predation as important, Forbes implicitly here suggests that predation, as most interactions in fish communities, is size structured (e.g. Persson et al. 2004), that is, also small individuals of top predator species are susceptible to predation. Such intraguild predation (e.g. Mehner et al. 1996) can originate from both inter- and intra-specific predation, as cannibalism is common among piscivorous fish (e.g. Giles et al. 1986; Smith and Reay 1991; Nilsson and Brönmark 1999). The direct effects of cannibalism can control top predator densities and thereby reduce the top-down trophic cascades from predation in aquatic systems (Grimm 1981; Carpenter and Kitchell 1993), as well as reduce the probability of success for biomanipulation of lake systems by adding piscivores (Skov and Nilsson 2007). Cannibalism and intraspecific interactions can have effects beyond direct predation. Agonistic interactions between piscivores are dangerous in the forms of possible injury, kleptoparasitism and mortality, and individuals trade off and alter behaviours to avoid such potential costs (Nilsson and Brönmark 1999; Nilsson 2006; Nilsson et al. 2006). If the trade-off invokes reduced activity and foraging, individuals avoiding interactions will have a reduced effect on prey, with consequences for community and trophic processes (Fryxell and Lundberg 1998; Nilsson 2001; Nilsson et al. 2007). Hence, behavioural responses may alter the encounter rates and the outcome of predator-prey interactions.

\section{Behavioural responses}

Hiding under stones and driftwood, insect larvae (our clarification) well aware, no doubt, what enticing morsels they are to a great variety of fishes (p. 544).

Exposure to potential predators often elicits behavioural responses in prey organisms, such as the one described by Forbes above. Unknown at that time was that many prey taxa are able to sense the presence of a predator through chemicals in both freshwater and marine ecosystems (Brönmark and Hansson 2000). The area of chemical ecology has expanded considerably and is currently a field of significant importance for many ecological studies (Brönmark and Hansson 2012). Generally, these aspects are studied between one predator and its prey, but multi-trophic responses have been observed, such as for planktivorous fish which hide in the vegetation in the presence of predators. This results in a "behavioural cascade" 
where zooplankton, previously hiding from planktivorous fish in the vegetation, leave this habitat since the open water is safer (Romare and Hansson 2003).

Although Forbes made very sharp observations of behavioural responses, his study was restricted to the summer season. An interesting, but often neglected, behavioural response occurring during winter is the mass-migration of planktivorous fish from the lake to streams and surrounding wetlands (Hansson et al. 2007; Brönmark et al. 2008). In many lakes, for example, L. Krankesjön, a considerable amount of planktivorous fish, some years up to $60 \%$ of the population, migrate from the lakes in autumn and back again in spring, and are actually away from the lake during a considerable part of the year! (Fig. 1). Such winter migrations have recently been shown to be a general phenomenon in many shallow lakes (Jepsen and Berg 2002; Skov et al. 2008, 2010, 2011). The likely driving force behind this mass-migration is the classical compromise where an organism has to balance the risk of predation against foraging opportunities, that is, an attempt to optimize the Predation risk/Growth potential ratio (P/G; (Hansson et al. 2007; Brönmark et al. 2008, 2010). However, also fall and spring temperatures affect the timing of the migratory event (Brodersen et al. 2011). Although a lot of fish are migrating, not all do (Fig. 1), suggesting that this is a partial migration phenomenon (Chapman et al. 2011a). Hence, depending on the amount of fish involved in the migration in a specific year, the effect from fish predation on lower trophic levels will differ

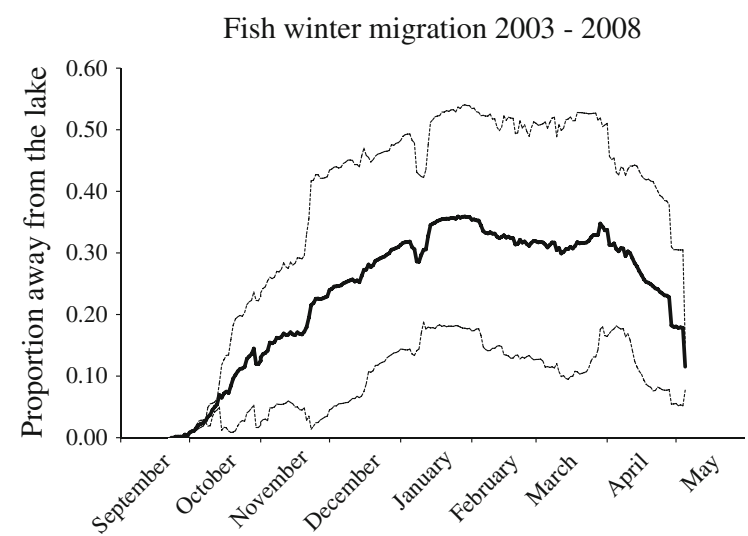

Fig. 1 Mean proportion (thick line) of fish migrating from L. Krankesjön to surrounding streams and wetlands from September to May 2003-2008. Thin lines represent standard deviations among years
(Hansson et al. 2007; Brodersen et al. 2011). Interestingly, the migratory behaviour is also affected by individual personality, that is, bold, more risk-taking, individuals are more prone to undertake migration than shy ones (Chapman et al. 2011b). Hence, our knowledge of winter ecology and individual behaviour has expanded somewhat since Forbes made his observations.

\section{Non-behavioural responses}

Prey not only respond behaviourally, but may also show morphological or physiological responses to predator presence, such as the classical Daphnia cyclomorphosis (Wesenberg-Lund 1900, 1908; Woltereck 1913; Laforsch and Tollrian 2004) or the predator-induced phenotypical change in crucian carp (Carassius carassius) (Brönmark and Miner 1992). Moreover, also Forbes observed and described nonbehavioural responses to predation risk, for example, regarding pelagic zooplankton:

These pelagic forms, as they are called, are often exquisitely transparent, and hence almost invisible in their native element-a charming device of Nature to protect them against their enemies in the open lake, where there is no chance of shelter or escape (p. 545).

Hence, by just observing, Forbes made the connection between zooplankton transparency and predator protection which has been repeatedly corroborated (Luecke and O'Brien 1981). Moreover, he also observed diel vertical migrations (DVM) in zooplankton, that is, combined behavioural and physiological responses:

Some (Entomostraca; our addition) prefer the open water, in which they throng locally like shoals of fishes, coming to the surface preferably by night, or on dark days, and sinking to the bottom usually by day to avoid the sunshine (p. 545).

Although Forbes correctly associated this DVM with zooplankton avoidance of sunshine (see above), we currently know that it is the ultraviolet (UV) radiation that they avoid, whereas zooplankton actually are attracted by visible light (Storz and Paul 1998). In addition, Forbes did not connect predator threat with DVM (Zaret and Suffern 1976; Dodson 1990), and did 
not observe that not all zooplankton are transparent. Instead, we now know that there are pigmented ones and that pigmentation differs depending on the predator threat, as well as the threat from ultraviolet radiation (Hansson and Hylander 2009a). Hence, with respect to the "exquisitely transparent" zooplankton, we now know that the transparency is not only a defence against predation, but also that the level of pigmentation is inducible at an individual level, that is, a trade-off between being protected against predators (fish) and UV radiation (Hansson and Hylander 2009a; Williamson et al. 2011). Moreover, to the defence strategies of zooplankton against fish predation and UV radiation, we may also add diel vertical migration (see above). Interestingly, all age classes of large cladoceran species (Daphnia magna) respond to UV radiation by rapidly swimming downwards (the Daphnia "light dance"; (Storz and Paul 1998). However, small-sized (young) Daphnia show little behavioural response to fish predator cues, whereas larger specimens react strongly to a potential predator threat, that is, Daphnia make size-structured risk assessments (Hansson and Hylander 2009b). Hence, within the area of zooplankton morphology, behaviour and defences, we can add some observations and mechanisms which make the overall picture of zooplankton ecology more complete.

\section{Competition}

And now, if we search for its (the bass; our clarification) competitors we shall find these also extremely numerous. In the first place, I have found that all our young fishes except Catostomidae feed at first almost wholly on Entomostraca, so that the little bass finds himself at the very beginning of his life engaged in a scramble for food with all the other little fishes in the lake (p. 548).

The observation that young individuals of predator species are competing with prey species has been expanded and studied in detail since Forbes days with respect to, for example, perch (Perca fluviatilis) and roach (Rutilus rutilus) (Persson 1983). However, competition and predation do not act independently of each other but in concert, as illustrated, for example, by a study in L. Krankesjön, where zooplankton were exposed to different levels of resources (algae) and predation from fish (Nicolle et al. 2011). The main conclusions here were that at low-predation pressure (low fish abundance), competition among zooplankton was most important for the population size. Moreover, zooplankton prey were able to withstand higher predation pressure at high than at low resource levels, that is, high resource supply buffers against predation at the population level (Nicolle et al. 2011).

\section{Population dynamics}

It is a self-evident proposition that a species can not maintain itself continuously, year after year, unless its birth-rate at least equals its death-rate. If it is preyed upon by another species, it must produce regularly an excess of individuals for destruction, or else it must certainly dwindle and disappear. On the other hand, the dependent species evidently must not appropriate, on average, any more than the surplus and excess of individuals of which it preys, for if it does so it will continuously diminish its own food supply and thus indirectly but surely exterminate itself (p. 549).

That predators rarely completely eradicate prey is commonly observed, for example, in herbivore-prey interactions between zoo- and phyto-plankton (Fig. 2) so this reflection by Forbes was, as so often, correct. However, he implicitly suggests in the above citation that it is some sort of an agreement between consumer and prey that the prey should produce food for the consumer and that the consumer should stop feeding when prey abundance becomes too low. He, more explicitly, say the same thing in the following paragraph:

... We thus see that there is really a close community of interest between these two seemingly deadly foes (predator and prey; our clarification) (p. 549).

We know now that there are no such agreements and it is not a "close community of interest" between predator and prey and that natural selection acts on individuals, not on groups. Instead we know that the predator would, if it had the opportunity, completely eradicate the prey. However, in natural systems this 


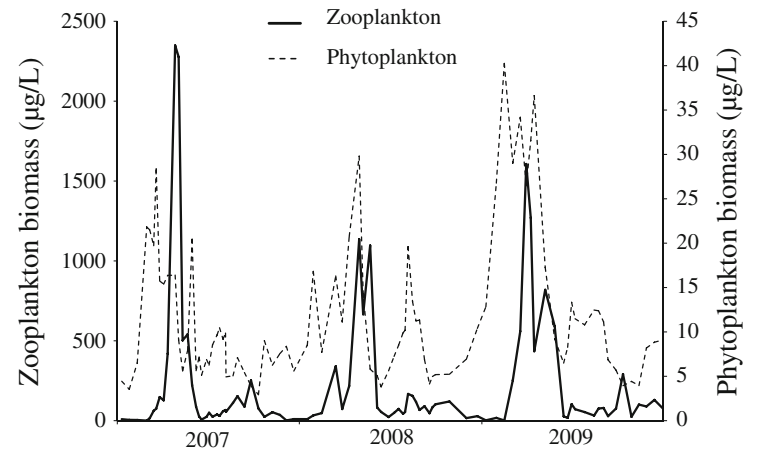

Fig. 2 Long-term fluctuations in algal (chlorophyll-a) and zooplankton biomasses $\left(\mu \mathrm{g} \mathrm{L}^{-1}\right)$ from L. Krankesjön during 2007-2009. Each spring phytoplankton (prey; dotted line) reaches maximum biomasses which are then consumed by a growing amount of herbivorous zooplankton (filled line) illustrating a repeated consumer-prey cycle

rarely occurs partly due to that at low prey abundances the encounter rate between predator and prey decreases (Fig. 2). Hence, a major difference between now and a century ago is that we are today not calculating with a "Mother nature" or a divine common interest among organisms. Although Darwin (1859) presented such thoughts a few decades before Forbes wrote his paper (1887), they had obviously not been fully adopted by Forbes. However, he let himself be inspired by many of the Darwinian concepts, such as "natural selection" (see below).

\section{Succession}

Along the same vein as for the predator-prey dynamics, Forbes reflected upon succession in freshwater systems:

Evidently each of this classes must act as a check upon the one preceding it. The development of animalcules (small animals; our clarification) is arrested and soon sent back below its highest point by the consequent development of Entomostraca; the latter, again, are met, checked, and reduced in number by the innumerable shoals of fishes with which the water speedily swarms (pp. 538-539).

This is the main concept of both temporal successions, described and discussed, for example, in the Plankton Ecology Group (PEG; (Sommer et al. 1986, 2012), and also the basis for the food web concept (Hrbácek et al.
1961; Carpenter et al. 1985). The predator-prey successions described have been shown repeatedly in many studies and also seen in the long-term fluctuations of the plankton community in L. Krankesjön, where the spring peak in algal biomass is rapidly grazed down by a growing cohort of herbivorous zooplankton (Fig. 2). Forbes described the "tidal wave of life" (p. 538) and that "... this fluctuation affects the different classes successively, in the order of their dependence upon each other for food", which can also be applied to the spring period when temperature increases. Then, algae increase in biomass, exploited by zooplankton and thereafter youngof-the-year (YOY) fish develop and start feeding, first on small zooplankton (rotifers) and then, as ontogeny proceeds, into larger zooplankton (Hansson et al. 2007; Nicolle et al. 2011).

\section{Waterfowl and macrophytes}

"All the northern and eastern part of the lake was visibly shallow - covered with weeds and feeding waterfowl” (p. 541)”; “... the shallower water black with water-fowl, and so clogged with weeds that a boat can scarcely be pushed through the mass ... (p. 542).

The water quality (clarity) of lake water is very important for the development of submerged macrophytes, and there is a strong positive relation between water clarity and macrophyte cover (Fig. 3). Moreover, submerged macrophytes are, in turn, very important for waterfowl, which has been an environmental issue since bird lakes are valued for recreational and ecosystem services (Marklund et al. 2002). The observation by Forbes that waterfowl rely heavily on submerged macrophytes ("weeds") has also been noted in the shallow L. Krankesjön, where waterfowl were virtually absent during periods when the lake was turbid from algae, such as in the beginning of the 1980s (Hansson et al. 2010), whereas they became very abundant when macrophytes returned, that is, there is a positive relation between macrophyte cover and bird abundance (Fig. 4). Hence, during fall migration, more than 2000 coot (Fulica atra; (Källander et al. 2009; Hansson et al. 2010)) take advantage of the extensive macrophyte beds (mainly Chara spp.). It should be noted that in L. Krankesjön not only birds directly feeding on macrophytes 
(herbivorous waterfowl, such as coot) respond to macrophyte expansions, but also, for example, diving ducks which feed on the immense amounts of invertebrates associated with the macrophytes (Fig. 4). This was described by Forbes as “... when lifting a handful of the latter (the macrophytes; our clarification), he finds them covered with shells and alive with small crustaceans" (p. 542) (Fig. 4; (Marklund et al. 2002; Hansson et al. 2010). Hence, with respect to the relationships between macrophytes, with associated invertebrates, and waterfowl, the progress during 125 years has mainly been that we now can quantify and provide correlations, whereas the main conceptual ideas were developed more than a century ago.

\section{Human influences on freshwater ecosystems}

\section{Recreational fishing}

I see no good reason why minnows should be so few, unless it be the abundance of pike and Chicago sportsmen (p. 544).

Pike (Esox lucius) are efficient piscivores that selectively forage on smaller size ranges of prey fish, despite their large gape sizes and remarkable abilities to consume large prey (Nilsson and Brönmark 1999, 2000; Nilsson et al. 2000). It is hence fully plausible that pike predation directly affects the abundance of

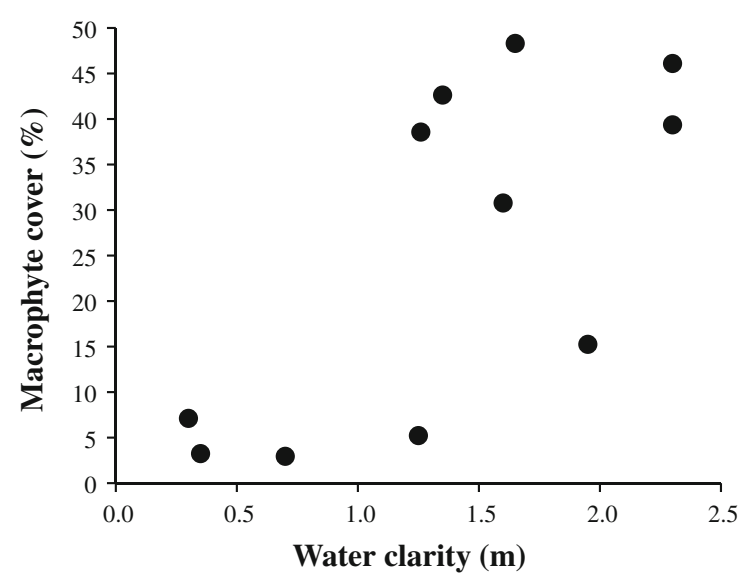

Fig. 3 The relation between water clarity (Secchi depth; m) and the macrophyte cover in L. Krankesjön $(r=0.71 ; t=2.56$; $p<0.030$ ). Each data point represents 1 year (data from Hansson et al. 2010) zooplanktivores, and keeps small fish, such as minnows, at comparably low densities. Pike further grow to very large sizes (Raat 1988), which is why they attract the attention of recreational anglers (Paukert et al. 2001; Arlinghaus and Mehner 2004). Intuitively, angling on pike may reduce pike densities and thereby also the effects of pike predation on small zooplanktivore densities. However, anglers commonly use live or dead fish as bait when fishing. High abundance of pike, attracting pike anglers, can hereby increase bait fishing and reduce local densities of small fish. Although it is unlikely that the Chicago sportsmen (see above) affected the abundance of bait fish, such as minnows, more than locally, fishing may indeed affect fish populations. In order to reduce this human impact,
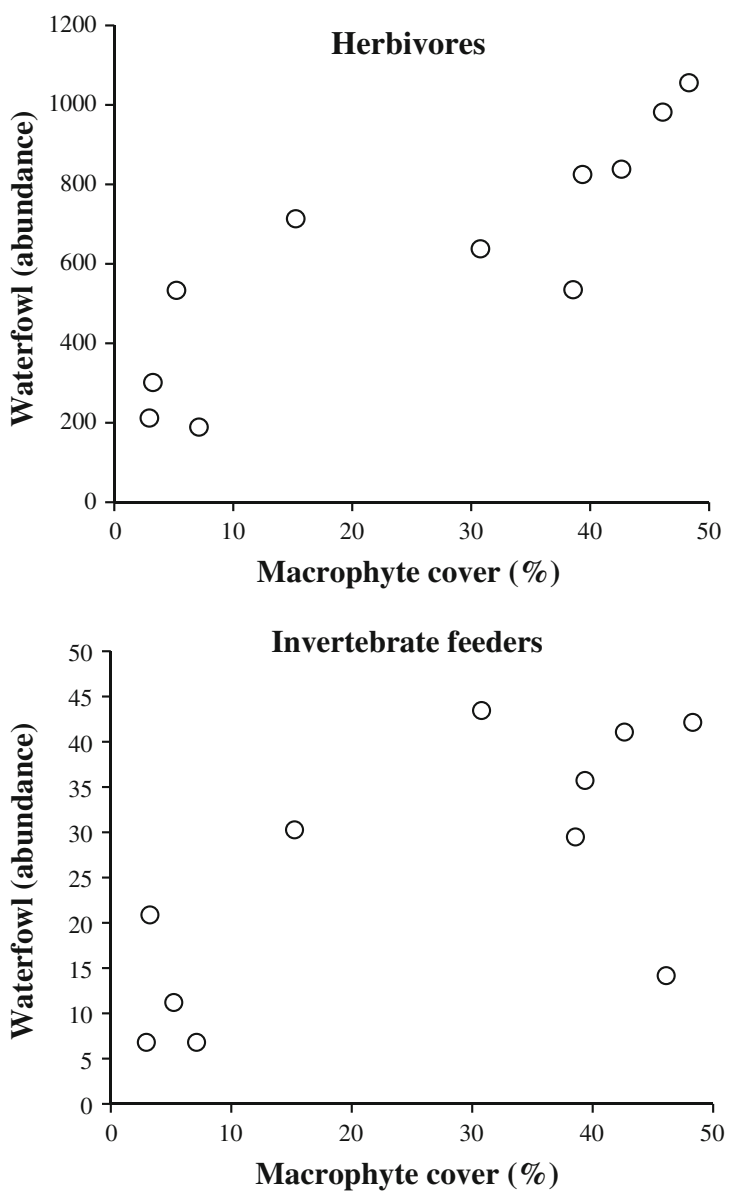

Fig. 4 The relation between macrophyte cover (\% of the bottom covered with macrophytes) and the number of resting herbivorous waterfowl, mainly coot (Fulica atra; $r=0.86$; $F=25.00 ; p<0.001)$ and invertebrate feeding waterfowl $(r=0.68 ; F=7.67 ; p<0.022)$ in Lake Krankesjön. Each data point represents 1 year (data from: Hansson et al. 2010) 
catch-and-release $(\mathrm{C} \& \mathrm{R})$ fishing is now commonly practiced, where caught fish are landed, unhooked and released at the capture location with the aim to cause fish as little harm as possible (Klefoth et al. 2008; Arlinghaus et al. 2009; Stålhammar et al. 2012). Although catch-and-release fishing was probably not practised 125 years ago, recreational fishing is a possible reason behind Forbes' comment on Chicago sportsmen, that is, even then recreational fishing might have affected fish populations.

\section{Environmental problems}

... These fluviatile lakes are most important breeding grounds and reservoirs of life, especially as they are protected from the filth and poison of towns and manufactories by which the running waters of the state are yearly more deeply defiled (p. 538).

A century ago, environmental problems were generally local and aquatic ecologists were little involved in solving environmental problems. Today, environmental problems are generally far more regional, or even global, and widespread (Brönmark and Hansson 2002), and few aquatic ecosystems are unaffected by, for example, eutrophication (Hansson et al. 1999), acidification (Stenson et al. 1993), alien chemicals (Bengtsson et al. 2004) or global climate change (Kosten et al. 2012; Hansson et al. 2013). Moreover, aquatic ecologists are today much more involved in identifying new potential environmental problems, such as the rapidly increasing release of nanoparticles to aquatic ecosystems through the sewage system (Cedervall et al. 2012). Aquatic ecologists are now also engaged in the process of solving, or at least rehabilitating, environmental problems, such as eutrophication through wetland construction (Hansson et al. 2005) and lake restoration, for example, by using biomanipulation (Hansson et al. 1998), which has been evaluated in large scale, for example, in Lake Ringsjön, situated close to L. Krankesjön in southern Sweden (Bergman et al. 1999). Fortunately, L. Krankesjön is little affected by environmental threats mainly as a result of low human population density and because the catchment is mainly used for extensive cattle grazing and as a military training area (Box 1). However, we have used water from L. Krankesjön in enclosure experiments addressing effects of environmental threats such as climate change, brownification and of endocrine disruptors (estrogens). Our primary findings here show that a temperature increase of $3{ }^{\circ} \mathrm{C}$-which is a moderate estimate of the temperature increase during the life time of the coming generation-will make the phytoplankton spring maximum advance about 2 weeks. Interestingly, however, small cladocerans, which is the main group of herbivores in L. Krankesjön, also advance their maximum abundance about 2 weeks, that is, we may not expect a mismatch between consumer and resource (Nicolle et al. 2012), which has been shown, for example, between phytoplankton and large cladocerans (Winder and Schindler 2004). Clearly, the knowledge of environmental threats has increased considerably during 125 years, although this is mainly due to that most of the environmental problems we have today did not exist in Forbes' days.

\section{Materials and methods}

In many scientific areas, the technological developments have been tremendous and a scientist 100 years ago would not be able to perform a study in, for example, a modern physics laboratory. This has also been the case in limnology, including molecular techniques, advanced chemical analyses, echo sounding techniques and also advanced monitoring devices, for example, the ones applied by the Global Lake Ecological Observatory Network (GLEON; (Hanson 2007). It might, however, be of some interest to compare the devices Forbes used with what a "modern" aquatic ecologist uses for general, routine field sampling. Forbes listed the following supplies:

“... using the sounding line, deep sea thermometer, towing net, dredge, and trawl ..." (p. 540). L. Krankesjön has been manually monitored more or less intensively during almost three decades. The major equipment used is a Plexiglas pipe for water sampling, a bucket, a $55 \mu \mathrm{m}$ net to sieve out zooplankton, a hand pump and a filter funnel to filter out chlorophyll. Hence, although we use GPS to find the exact sampling spot, the equipment used for sampling is, at least in our study lake, at a similar technological level as that used 125 years ago. Hence, although the technological advancements have been considerable, allowing new questions to be answered, the techniques and methods used by Forbes are to a large extent still appropriate. 


\section{Divine intrusions}

In the text of Forbes, there is a multitude of both implicit and explicit references to a divine order, which is not far from what is still argued by apostles of, for example, the Intelligent Design movement (e.g. www.intelligentdesign.org). Below we provide some examples:

For every defensive device with which she ("Nature"; our clarification) has armed an animal, she has invented a still more effective apparatus of destruction and bestowed it upon some foe, thus striving with unending pertinacity to outwit herself (p. 549).

Whether or not Forbes used such references because he really believed in them or because he aimed at improving public relations, that is, to reach out with his message, is, of course, unknown to us. We may, however, state that irrespective of Forbes' own thoughts, modern ecological and evolutionary science has found explanations and causalities that are not including any divine intrusions. Hence, within this area, considerable advancements have been achieved during the last century. Notable is, however, that among the divine associations, Forbes added an expression that was, at that time, very modern and radical: natural selection as a driving force for evolution:

And next we note that this common interest is promoted by the process of natural selection; for it is the great office of this process to eliminate the unfit (p. 549).

Hence, irrespective of his own conviction, Forbes here paved the road from the previous religious way of viewing nature, to the new era where, for example, natural selection is a central issue. Moreover, this also indicates that Forbes was open to new concepts that could explain mechanisms and processes without involvement of religious explanations. For a natural scientist today, this may sound obvious, but was certainly provocative to express 125 years ago.

\section{Lakes as microcosms-with extensions}

To categorize lakes as microcosms is both a thought provoking and attractive approach. Lakes are, indeed, more closed than most terrestrial and marine biomes which makes them suitable for ecological studies since most organisms remain in the study system (the lake) throughout their life. However, lakes might not be entirely closed microcosms, which also shines through the Forbes' paper. For example, the sportsmen of Chicago (p. 544) are taking out fish biomass, and nutrients and pollutants (p. 538) are entering the lake through tributaries. Moreover, a lake is often viewed as a mirror of its catchment, that is, affected by, for example, humic substances, causing "brownification" (Graneli 2012). We here also add the winter mass-migrations of fish to these exchanges with other biomes. Hence, a lake might be a microcosm compared to a terrestrial environment, but it has, indeed, extensions and is by no means isolated.

Irrespective of whether lakes should be viewed as microcosms or not, the paper by Forbes has been exceptionally influential and is, indeed, still a source for curiosity and creativity especially since he touched upon almost all aspects of the lake ecosystem, from individual behaviour to food web interactions and environmental issues. Hence, there is no doubt that even if 125 years have passed, Forbes' paper still deserves to be read and included in literature lists for $\mathrm{PhD}$ students, and although aquatic ecology has made considerable progress over the latest century, Forbes might be viewed as a scientist who paved the intellectual road for most of us.

Acknowledgments We thank the Editors Piet Spaak, Thomas Mehner, Bas Ibelings and Liesbeth Bakker for inviting us to write this manuscript. The long-term funding from The Swedish Research Council (vr) and The Swedish Research Council for the Environment and Spatial Planning (Formas) made it possible to provide data for this comparative study.

\section{References}

Arlinghaus R, Mehner T (2004) A management-oriented comparative analysis of urban and rural anglers living in a metropolis (Berlin, Germany). Environ Manag 33:331-344

Arlinghaus R, Klefoth T, Cooke SJ, Gingerich A, Suski C (2009) Physiological and behavioural consequences of catch-andrelease angling on northern pike (Esox lucius L.). Fish Res 97:223-233

Bengtsson G, Hansson L-A, Montenegro K (2004) Reduced grazing rates in Daphnia pulex caused by contaminants: implications for trophic cascades. Environ Toxicol Chem 23:2641-2648

Bergman E, Hansson L-A, Persson A, Strand JA, Romare P, Enell M, Granéli W, Svensson JM, Hamrin S, Cronberg G, Andersson G, Bergstrand E (1999) Synthesis of the theoretical and empirical experiences from nutrient and cyprind reductions in Lake Ringsjön. Hydrobiologia 404:145-156 
Blindow I, Hargeby A, Meyercordt J, Schubert H (2006) Primary production in two shallow lakes with contrasting plant form dominance: a paradox of enrichment? Limnol Oceanogr 51:2711-2721

Brodersen J, Nicolle A, Nilsson PA, Skov C, Bronmark C, Hansson L-A (2011) Interplay between temperature, fish partial migration and trophic dynamics. Oikos 120:1838-1846

Brönmark C, Hansson L-A (2000) Chemical communication in aquatic systems: an introduction. Oikos 88:103-111

Brönmark C, Hansson L-A (2002) Environmental issues in lakes and ponds: current state and future perspective. Environ Conserv 29:290-306

Brönmark C, Hansson L-A (eds) (2012) Chemical Ecology in Aquatic Systems. Oxford University Press

Brönmark C, Miner JG (1992) Predator-induced phenotypical change in crucian carp. Science 258:1348-1350

Brönmark C, Skov C, Brodersen J, Nilsson PA, Hansson L-A (2008) Seasonal migration determined by a trade-off between predator avoidance and growth. PLoS One 3:e1957

Brönmark C, Brodersen J, Chapman BB, Nicolle A, Nilsson PA, Skov C, Hansson L-A (2010) Regime shifts in shallow lakes: the importance of seasonal fish migration. Hydrobiologia 646:91-100

Carpenter SR, Kitchell JF (1993) The trophic cascade in lakes. Cambridge University Press, Cambridge

Carpenter SR, Kitchell JF, Hodgson JR (1985) Cascading trophic interactions and lake productivity: fish predation and herbivory can regulate lake ecosystem. Bioscience 35 : 634-639

Cedervall T, Hansson L-A, Lard M, Frohm B, Linse S (2012) Food chain transport of nanoparticles affects behaviour and fat metabolism in fish. PLoS One 7:e32254

Chapman BB, Brönmark C, Nilsson JA, Hansson L-A (2011a) The ecology and evolution of partial migration. Oikos 120: 1764-1775

Chapman BB, Hulthen K, Blomqvist DR, Hansson L-A, Nilsson JA, Brodersen J, Nilsson PA, Skov C, Brönmark C (2011b) To boldly go: individual differences in boldness influence migratory tendency. Ecol Lett 14:871-876

Darwin C (1859) On the origin of species by means of natural selection. John Murray, London

Dodson S (1990) Predicting diel vertical migration of zooplankton. Limnol Oceanogr 35:1195-1200

Forbes S (1926) The lake as a microcosm. Bull Ill Nat Hist Surv 15:537-550

Fryxell JM, Lundberg P (1998) Individual behavior and community dynamics. Chapman \& Hall, London

Giles N, Wright MR, Nord ME (1986) Cannibalism in pike fry, Esox lucius L.: some experiments with fry densities. J Fish Biol 29:107-113

Graneli W (2012) Brownification of lakes. In: Bengtsson L, Herschy, R. W., Fairbridge, R. (ed) Encyclopedia of Lakes and Reservoirs

Grimm MP (1981) Intraspecific predation as a principal factor controlling the biomass of northern pike (Esox lucius L.). Fish Manag 12:77-79

Hairston NG, Smith FE, Slobodkin LB (1960) Community structure, population control, and competition. Am Nat XCIV:421-425
Hanson PC (2007) A grassroots approach to sensor and science networks. Front Ecol Environ 5:343

Hansson L-A, Hylander S (2009a) Effects of ultraviolet radiation on pigmentation, photoenzymatic repair, behavior, and community ecology of zooplankton. Photochem Photobiol Sci 8:1266-1275

Hansson L-A, Hylander S (2009b) Size-structured risk assessments govern Daphnia migration. Proc R Soc B 276:331-336

Hansson L-A, Annadotter H, Bergman E, Hamrin SF, Jeppesen E, Kairesalo T, Luokkanen E, Nilsson P-Å, Søndergaard M, Strand JA (1998) Biomanipulation as an application of food chain theory: constraints, synthesis and recommendations for temperate lakes. Ecosystems 1:558-574

Hansson L-A, Enell M, Bergman E (1999) Lake Ringsjon: its catchment area, its history and its importance. Hydrobiologia 404:1-7

Hansson L-A, Brönmark C, Nilsson PA, Åbjornsson K (2005) Conflicting demands on wetland ecosystem services: nutrient retention, biodiversity or both? Freshw Biol 50:705-714

Hansson L-A, Nicolle A, Brodersen J, Romare P, Skov C, Nilsson PA, Brönmark C (2007) Consequences of fish predation, migration and juvenile ontogeny on zooplankton spring dynamics. Limnol Oceanogr 52:696-706

Hansson L-A, Nicolle A, Brönmark C, Hargeby A, Lindström A, Andersson G (2010) Waterfowl, macrophytes, and the clear water state of shallow lakes. Hydrobiologia 646: 101-109

Hansson L-A, Nicolle A, Granéli W, Hallgren P, Kritzberg E, Persson A, Nilsson AP, Brönmark C (2013) Food chain length alters community responses to global change in aquatic systems. Nat Clim Change 3:228-233

Hargeby A, Andersson G, Blindow I, Johanson S (1994) Trophic web structure in a shallow eutrophic lake during a dominance shift from phytoplankton to submerged macrophytes. Hydrobiologia 279(280):83-90

Hrbácek J, Dvorakova M, Korínek V, Prochákóva L (1961) Demonstration of the effect of the fish stock on the species composition of zooplankton and the intensity of metabolism of the whole plankton association. Verh Int Ver Limnol 14:192-195

Jepsen N, Berg S (2002) The use of winter refuges by roach tagged with miniature radio transmitters. Hydrobiologia 483: $167-173$

Källander H, Hansson L-A, Brönmark C, Nicolle A (2009) Waterfowl in Lake Krankesjön. Ornis Svecica 19:65-87

Klefoth T, Kobler A, Arlinghaus R (2008) The impact of catchand-release on short term behaviour and habitat choice of northern pike (Esox lucius L.). Hydrobiologia 601:99-110

Kosten S, Huszar VLM, Becares E, Costa LS, van Donk E, Hansson L-A, Jeppesen E, Kruk C, Lacerot G, Mazzeo N, De Meester L, Moss B, Lurling M, Noges T, Romo S, Scheffer M (2012) Warmer climates boost cyanobacterial dominance in shallow lakes. Glob Change Biol 18:118126

Laforsch C, Tollrian R (2004) Inducible defences in multipredator environments: cyclomorphosis in Daphnia cucculata. Ecology 85:2302-2311

Lindeman R (1942) The trophic-dynamic aspect of ecology. Ecology 23:399-418 
Luecke C, O'Brien WJ (1981) Phototoxicity and fish predation: selective factors in color morphs in Heterocope. Limnol Oceanogr 26:454-460

Marklund O, Sandsten H, Hansson L-A, Blindow I (2002) Effects of waterfowl and fish on submerged vegetation and macroinvertebrates. Freshw Biol 47:2049-2059

Mehner T, Schultz H, Bauer D, Herbst R, Voigt H, Benndorf J (1996) Intraguild predation and cannibalism in age-0 perch (Perca fluviatilis) and age-0 zander (Stizostedion lucioperca): interactions with zooplankton succession, prey fish availability and temperature. Ann Zool Fennici 33:353-361

Nicolle A, Hansson L-A, Brodersen J, Nilsson PA, Bronmark C (2011) Interactions between predation and resources shape zooplankton population dynamics. PLoS One 6:e16534

Nicolle A, Hallgren P, von Einem J, Kritzberg E, Granéli W, Persson A, Brönmark C, Hansson L-A (2012) Predicted warming and browning affect timing and magnitude of plankton phenological events in lakes: a mesocosm study. Freshw Biol 57:684-695

Nilsson PA (2001) Predator behaviour and prey density: evaluating density-dependent intraspecific interactions on predator functional responses. J Anim Ecol 70:14-19

Nilsson PA (2006) Avoid your neighbours: size-determined spatial distribution patterns among northern pike individuals. Oikos 113:251-258

Nilsson PA, Brönmark C (1999) Foraging among cannibals and kleptoparasites: effects of prey size on pike behavior. Behav Ecol 10:557-566

Nilsson PA, Brönmark C (2000) Prey vulnerability to a gapesize limited predator: behavioural and morphological impacts on northern pike piscivory. Oikos 88:539-546

Nilsson PA, Nilsson K, Nyström P (2000) Does risk of intraspecific interactions induce shifts in prey-size preference in aquatic predators? Behav Ecol Sociobiol 48:268-275

Nilsson PA, Turesson H, Brönmark C (2006) Friends and foes in foraging: intraspecific interactions act on foraging-cycle stages. Behaviour 143:733-745

Nilsson PA, Lundberg P, Brönmark C, Persson A, Turesson H (2007) Behavioral interference and facilitation in the foraging cycle determine the functional response. Behav Ecol 18:354-357

Paukert CP, Klammer JA, Pierce RB, Simonson TD (2001) An overview of Northern pike regulations in North America. Fisheries 26:6-13

Persson L (1983) Effects of intra-and interspecific competition on dynamics and size structure of a perch (Perca fluviatilis) and a roach (Rutilus rutilus) population. Oikos 41:126-132

Persson L, Byström P, Wahlström E, Westman E (2004) Trophic dynamics in a whole lake experiment: size-structured interactions and recruitment variation. Oikos 106:263-274

Raat AJP (1988) Synopsis of the biological data on the northern pike, Esox lucius Linnaeus, 1758. FAO Fisheries Synopsis: No. 30, Rev. 32, p 178

Romare P, Hansson L-A (2003) A behavioral cascade: toppredator induced behavioral shifts in planktivorous fish and zooplankton. Limnol Oceanogr 48:1956-1964
Skov C, Nilsson PA (2007) Evaluating stocking of YOY pike Esox lucius $\mathrm{L}$. as a tool in the restoration of shallow lakes. Freshw Biol 52:1834-1845

Skov C, Brodersen J, Nilsson PA, Hansson L-A, Brönmark C (2008) Inter- and size-specific patterns of fish seasonal migration between a shallow lake and its streams. Ecol Freshw Fish 17:406-415

Skov C, Aarestrup K, Baktoft H, Brodersen J, Brönmark C, Hansson L-A, Nielsen EE, Nielsen T, Nilsson PA (2010) Influences of environmental cues, migration history, and habitat familiarity on partial migration. Behav Ecol 21:1140-1146

Skov C, Baktoft H, Brodersen J, Brönmark C, Chapman B, Hansson L-A, Nilsson PA (2011) Sizing up your enemy: individual predation vulnerability predicts migratory probability. Proc R Soc B 278:1414-1418

Smith C, Reay P (1991) Cannibalism in teleost fish. Rev Fish Biol Fish 1:41-64

Sommer U, Gliwicz ZM, Lampert W, Duncan A (1986) The PEG-model of seasonal succession of planktonic events in fresh waters. Arch Hydrobiol 106:433-471

Sommer U, Adrian R, Domis LD, Elser JJ, Gaedke U, Ibelings B, Jeppesen E, Lurling M, Molinero JC, Mooij WM, van Donk E, Winder M (2012) Beyond the Plankton Ecology Group (PEG) model: mechanisms driving plankton succession. Annu Rev Ecol Evol S 43:429-448

Stålhammar M, Linderfalk R, Brönmark C, Arlinghaus R, Nilsson PA (2012) The impact of catch-and-release on the foraging behaviour of pike (Esox lucius) when released alone or into groups. Fish Res 125-126:51-56

Stenson JAE, Svensson JE, Cronberg G (1993) Changes and interactions in the pelagic community in acidified lakes in Sweden. Ambio 22:277-282

Storz UC, Paul RJ (1998) Phototaxis in water fleas (Daphnia magna) is differently influenced by visible and UV light. J Comp Physiol A 183:709-717

Wesenberg-Lund C (1900) Von dem Abhangigkeitsverhiiltnis zwischen dem Bau der Planktonorganismen und dem spezifischen Gewicht des Siisswassers. Bioi Zentralbl 20:606-619

Wesenberg-Lund C (1908) Plankton investigations of Danish Lakes. Danish Freshwater Biology Laboratory, vol 5

Williamson CE, Fischer JM, Bollens SM, Overholt EP, Breckenridge JK (2011) Toward a more comprehensive theory of zooplankton diel vertical migration: integrating ultraviolet radiation and water transparency into the biotic paradigm. Limnol Oceanogr 56:1603-1623

Winder M, Schindler DE (2004) Climate change uncouples trophic interactions in an aquatic ecosystem. Ecology 85:2100-2106

Woltereck R (1913) Uber Funktion, Herkunft und Entstehungsursachen der sogenannten 'Schwebe-Fortsatze' pelagischer Cladoceren. Zool Sci 67:474-550

Zaret TM, Suffern JS (1976) Vertical migration in zooplankton as a predator avoidance mechanism. Limnol Oceanogr 21:804-813 